\title{
Ovarian Reserve Tests and Their Application to Infertility Management
}

\author{
Prasanna Raj Supramaniam, Monica Mittal² and Lee Nai Lim MRCOG ${ }^{3}$ \\ ${ }^{1}$ Specialist Registrar in Obstetrics \& Gynaecology, Oxford University Hospitals NHS Foundation Trust, UK \\ ${ }^{2}$ Subspecialist Trainee in Reproductive Medicine and Surgery, Specialist Registrar in Obstetrics \& Gynaecology, Oxford University Hospitals NHS \\ Foundation Trust, UK \\ ${ }^{3}$ Consultant in Reproductive Medicine and Surgery, Obstetrics and Gynaecology, Oxford University Hospitals NHS Foundation Trust, UK
}

Submission: August 19, 2017; Published: August 29, 2017

*Corresponding author: Prasanna Raj Supramaniam, Specialist Registrar in Obstetrics \& Gynaecology, Oxford University Hospitals NHS Foundation Trust, UK, Email: prasannaraj@doctors.org.uk

\section{Opinion}

Over the years, the family dynamics have changed. Couples are either delaying the start of their family or individuals are seeking treatment alone. This is increasing the number of people seeking assistance through reproductive clinics. To counsel patients' effectively, a greater understanding of fertility potential is needed. There is still yet to be a single definitive test that is able to evaluate ovarian reserve and predict the outcome. Multiple investigations are currently used to assign treatment protocols. In the United Kingdom, the National Health Service (NHS), is unable to fund all investigations discussed within this article, due to limited evidence supporting their role and efficacy.

Follicle Stimulating Hormone (FSH) is an essential hormone in the menstrual cycle. It is synthesized and secreted by the anterior pituitary. The main role of this hormone is the development of graafian follicles from an immature to a mature follicle during the follicular phase of the cycle. Day 2-5 FSH is currently a routine test performed to evaluate ovarian response in patients seeking fertility treatment and is often used as a predictor for the success of Assisted Reproductive Treatments (ART) [1]. Age and Day 3 serum FSH levels used in combination are superior predictive markers of ART outcomes [2]. A metaanalysis of 21 studies has demonstrated basal FSH levels to be a moderate predictor of diminishing ovarian response. The recommendation from this meta-analysis was that basal FSH in women undergoing ART, should not be used as a single indicator of ovarian reserve [3].

A good body of evidence suggests that age when compared to basal FSH levels is a better predictor of ovarian reserve. A study including 1045 women who were undergoing their first IVF cycle, revealed that basal FSH levels alone could not accurately predict pregnancy outcomes, however, age was seen to be a better predictor [4]. It was also noted that high FSH levels are more prevalent in women above 35 years of age. In another study including more than 300 women looking at basal FSH levels and ongoing pregnancy rates, the study concluded that there was a general decline in pregnancy rate with an increase in FSH levels. The group of patients with a FSH level of less than 10IU/L had a $65 \%$ ongoing pregnancy rate compared to the group with a FSH level of more than $15 \mathrm{IU} / \mathrm{l}$ who had a $28 \%$ ongoing pregnancy rate [5].

Antral follicles are commonly referred to as resting follicles. They are noted to be small in diameter, mostly between 2 to $8 \mathrm{~mm}$ and are normally measured via transvaginal ultrasonography. It has been seen that the reproductive age can be predicted based on the total antral follicle count [6]. A study comparing women $(\mathrm{n}=83$ ) with different types of ovaries focused on women with a history of ovarian cystectomy performed for an endometrioma, known existing endometrioma and women with unaffected ovaries. The results demonstrated no difference in the antral follicile count between either groups. However, a statistically significant result was seen for the area under the curve for the prediction of low response, 0.83 (95\% CI 0.68-0.99), and over response, 0.84 (95\% CI 0.70-0.97) [7].

A meta-analysis including 10 studies looking at ovarian volume and 17 studies looking at antral follicle count showed that due to significant heterogeneity the sensitivity and specificity of these studies were inaccurate. However, the authors concluded that the antral follicle count was a better predictor of ovarian reserve compared to the measurement of ovarian volume via ultrasound [8]. One of the major challenges with ultrasonography is reproducibility. A study looking at 29 women revealed that three-dimensional ultrasonography and power Doppler angiography created excellent intra and inter observer reproducibility. In this study, the authors mainly evaluated the 
assessment of ovarian response and oocyte quality. The results revealed that the coefficients for both groups were close to unity in the ovarian volume category, and 0.964 for intra observer and 0.978 for inter observer in reference to the antral follicle count measurements [9].

Anti-Mullerian hormone (AMH) is a glycoprotein that is secreted from the granulosa cells of the pre-antral and small antral follicles of the ovary from 36 weeks gestation [10]. The main function of AMH is to inhibit the primordial follicles from being recruited into the antral follicle pool [11]. AMH also has a significant advantage over basal FSH wherein it is not altered by intra cycle or inter cycle variability [12]. This allows AMH to be reliably measured at any point during the menstrual cycle. One of the challenges in interpreting $\mathrm{AMH}$ results in the general population is the variation in the assay. Evidence has been published highlighting differing outcomes with the use of different assays in the same population. This therefore limits the role of AMH and the context in which it is used. However, it is well established that the extremes of AMH results have a reliable prediction of fertility potential [13].

When compared to antral follicle count, AMH has been seen to be on par in the assessment of ovarian reserve [14], however, it is seen to be superior when compared to FSH and Inhibin B levels [15].

Serum Inhibin B is a polypeptide mainly found in the follicular phase of the menstrual cycle. It is secreted by the granulosa cells of the antral follicles [16]. The levels of Inhibin $\mathrm{B}$ are normally seen to peak during the early follicular phase [17]. A study that looked at the value of Inhibin B, demonstrated that women with an Inhibin B value above $45 \mathrm{pg} / \mathrm{ml}$ had a better estrogenic response to stimulation, reduced cancellation rates, higher pregnancy rates and increased oocyte retrieval [18]. When comparing ART success, a study looking at 120 women found that basal FSH was a better predictor of outcome compared to Inhibin B. These women had blood drawn at a 3-month interval following their IVF attempt to assess the levels of FSH and Inhibin B [19]. However, it has been shown that serum and follicular Inhibin B levels have a strong correlation with the number of oocytes retrieved, but sadly the same cannot be said for the prediction of pregnancy rates [20].

When looking at dynamic testing the serum estradiol response to exogenous FSH administration has been seen to be a reliable predictor of implantation and pregnancy rates. Women who have had an estradiol level above 30pg/ml 24 hours following the administration of exogenous FSH have had higher implantation and pregnancy rates compared to patients with values below 30pg/ml [21]. This test is called exogenous FSH ovarian reserve test (EFFORT).

In some local centers, clinicians also use the clomiphene citrate challenge test. This involves performing a basal FSH level on Day 3 followed by the routine administration of clomiphene citrate for 5 days of the cycle starting on Day 5 up to Day 9. This is then completed with a repeat serum FSH level on Day 10. Patients who fall into the category of FSH level above 12.5 units are thought to be comparable to patients who have a normal basal FSH level in terms of predictability of pregnancy outcomes [16].

It is clearly evident from the literature available and the significant variation in practice that there is still yet to be a single test to be hailed as a gold standard investigation for ovarian reserve testing. The test available to clinicians today when used with caution and generous counseling is able to produce a result that is in keeping with scientific needs. The difficulty therein lies in what a patients understanding of these needs would be and the clinicians ability to counsel the patients appropriately. There are also other limiting factors in this cohort of patients to consider such as age and body mass index, with the clinician needing to make a sound judgment with the available evidence. This is surely an art that is honed with experience, which is a trade built with time and effort.

\section{References}

1. Muasher SJ, Oehninger S, Simonetti S, Matta J, Ellis LM, et al. (1988) The value of basal and/or stimulated serum gonadotropin levels in prediction of stimulation response and in vitro fertilization outcome. Fertil Steril 50(2): 298-307.

2. Toner JP, Philput C, Jones GS, Muasher SJ (1991) Basal folliclestimulating hormone level is a better predictor of in vitro fertilization performance than age. Fertil Steril 55(4): 784-791.

3. Bancsi LF, Broekmans FJ, Mol BW, Habbema JD, te Velde (2003) Performance of basal follicle-stimulating hormone in the prediction of poor ovarian response and failure to become pregnant after in vitro fertilization: a meta-analysis. Fertil Steril 79(5): 1091-1100.

4. Chuang CC, Chen CD, Chao KH, Chen SU, Ho HN, et al. (2003) Age is a better predictor of pregnancy potential than basal follicle- stimulating hormone levels in women undergoing in vitro fertilization. Fertil Steril 79(1): 63-68.

5. Van Rooij IA, de Jong E, Broekmans FJ, Looman CW, Habbema JD, et al. (2004) High follicle- stimulating hormone levels should not necessarily lead to the exclusion of subfertile patients from treatment. Fertil Steril 81(6): 1478-1485.

6. Scheffer GJ, Broekmans FJ, Looman CW, Blankenstein M, te Jong FH, et al. (2003) The number of antral follicles in normal women with proven fertility is the best reflection of reproductive age. Hum Reprod 18(4): 700-706.

7. Benaglia L, Candotti G, Busnelli A, Paffoni A, Vercellini P, et al. (2015) Antral follicle count as a predictor of ovarian responsiveness in women with endometriomas or with a history of surgery for endometriomas. Fertil Steril 103(6): 1544-1550.

8. Hendriks DJ, Kwee J, Mol BW, te Velde ER, Broekmans FJ (2007) Ultrasonography as a tool for the prediction of outcome in IVF patients: a comparative meta-analysis of ovarian volume and antral follicle count. Fertil Steril 87(4): 764-775.

9. Merce LT, Gomez B, Engels V, Bau S, Baio JM (2005) Intraobserver and interobserver reproducibility of ovarian volume, antral follicle count, and vascularity indices obtained with transvaginal 3-dimensional ultrasonography, power Doppler angiography, and the virtual organ computer-aided analysis imaging program. J Ultrasound Med 24(9): 1279-1287. 


\section{Current Research in Diabetes \& Obesity Journal}

10. Rajperts de Meyts E, Jorgensen N, Graem N, Muller J, Cate RL, et al. (1999) Expression of anti-Mullerian hormone during normal and pathological gonadal development: association with differentiation of Sertoli and granulosa cells. J Clin Endocrinol Metab 84(10): 38363844 .

11. Themmen AP (2005) Anti-Mullerian hormone: its role in follicular growth initiation and survival and as an ovarian reserve marker. J Natl Cancer Inst Monogr (34): 18-21.

12. La Marca A, Stabile G, Artenisio AC, Volpe A (2006) Serum antiMullerian hormone throughout the human menstrual cycle. Hum Reprod 21(12): 3103-3107.

13. Nelson SM, Yates RW, Lyall H, Jamieson M, Traynor I, et al. (2009) AntiMüllerian hormone-based approach to controlled ovarian stimulation for assisted conception. Hum Reprod 24(4): 867-875.

14. de Vet A, Loven JS, de Jong FH, Themmen AP, Fauser BC (2002) AntiMullerian hormone serum levels: a putative marker for ovarian aging. Fertil Steril 77(2): 357-362.

15. Barad DH, Weghofer A, Gleicher N (2009) Comparing anti-Müllerian hormone $(\mathrm{AMH})$ and follicle-stimulating hormone (FSH) as predictors of ovarian function. Fertil Steril 91(4): 1553-1555.
16. Sajal Gupta, Dipika Sharma, Nilopher Surti, Shubhangi Kesavan, Pallavi Khanna, et al. (2009) Ovarian reserve testing: systematic review of the literature. Arch Med Sci 5(1): 143-150.

17. Groome NP, Illingworth PJ, O’Brien M (1994) Detection of dimeric inhibin throughout the human menstrual cycle by two-site enzyme immunoassay. Clin Endocrinol (Oxf) 40(6): 717-723.

18. Seifer DB, Lambert Messerlian G, Hogan JW, Gardiner AC, Blazar AS, et al. (1997) Day 3 serum inhibin-B is predictive of assisted reproductive technologies outcome. Fertil Steril 67(1): 110-114.

19. Creus M, Penarrubia J, Fabregues F, Ester V, Francisco C, et al. (2000) Day 3 serum inhibin $\mathrm{B}$ and FSH and age as predictors of assisted reproduction treatment outcome. Hum Reprod 15(11): 2341-2346.

20. Fried G, Remaeus K, Harlin J, Krog E, Csemiczky G, et al. (2003) Inhibin $B$ predicts oocyte number and the ratio IGF-I/IGFBP-1 may indicate oocyte quality during ovarian hyperstimulation for in vitro fertilization. J Assist Reprod Genet 20(5): 167-176.

21. Fanchin R, de Ziegler D, Olivennes F, Taieb J, Dzik A, et al. (1994) Exogenous follicle stimulating hormone ovarian reserve test (EFORT): a simple and reliable screening test for detecting poor responders in vitro fertilization. Hum Reprod 9(9): 1607-1611.

\section{Your next submission with Juniper Publishers} will reach you the below assets

- Quality Editorial service

- Swift Peer Review

- Reprints availability

- E-prints Service

- Manuscript Podcast for convenient understanding

- Global attainment for your research

- Manuscript accessibility in different formats

( Pdf, E-pub, Full Text, Audio)

- Unceasing customer service

Track the below URL for one-step submission https://juniperpublishers.com/online-submission.php 